Bull. Chem. Soc. Ethiop. 2019, 33(1), 143-148.

ISSN 1011-3924

(c) 2019 Chemical Society of Ethiopia and The Authors

Printed in Ethiopia

DOI: https://dx.doi.org/10.4314/bcse.v33i1.14

\title{
A FACILE SYNTHESIS OF 1-ARYL PYRROLES BY CLAUSON-KAAS REACTION USING OXONE AS A CATALYST UNDER MICROWAVE IRRADIATION
}

\author{
Kumaraswamy Gullapelli $^{1 *}$, G. Brahmeshwari ${ }^{2}$ and M. Ravichander ${ }^{1}$ \\ ${ }^{1}$ Department of chemistry, Mahatma Gandhi Institute of Technology, Hyderabad-India-500075 \\ ${ }^{2}$ Department of Chemistry, Kakatiya University, Warangal-India-506009
}

(Received June 7, 2018; Revised November 1, 2018; Accepted November 9, 2018)

\begin{abstract}
A new and efficient methodology to synthesize N-substituted pyrrole derivatives by Clauson Kaas reaction employing Oxone as catalyst was developed. The transformation was performed in acetonitrile under microwave irradiation. This procedure has several advantages such as high yield, clean product formation, and short reaction time.
\end{abstract}

KEY WORDS: Synthesis, Pyrrole, Oxone, Microwave irradiation

\section{INTRODUCTION}

The study of heterocyclic compounds is an evergreen field in organic chemistry. It always attracts the attention of scientists working not only in the area of natural compounds but also in synthetic organic chemistry, specifically with Nitrogen containing heterocyclic structural unit exhibits a wide range of biological activities through effective binding to enzyme receptor site.

As per the present research reports, thousands of new heterocyclic compounds either isolated from natural sources or synthesized in the laboratories are added to the literature every year. Many of these compounds have drawn the attention in various fields like natural product synthesis, functional materials, ligands, biological and pharmacological activities [1-6]. Among nitrogen containing five-member heterocycles, pyrrole is one of the modest class of heterocyclic compounds possessing wide range of biological activities, such as antimicrobial [7-8], antiviral [9], antitumor [10], anti-inflammatory [11] and antioxidant [12]. In addition, there is a growing interest in the synthesis of substituted pyrroles in the area of materials chemistry [13-14].

The Clauson-Kaas reaction between primary amines and 2,5-dimethoxytetrahydrofuran remains as an attractive possibility [15-18], which has received great attention because it allows the synthesis of pyrroles without substituents on the carbon atoms of the heterocycle. Different catalysts and reaction conditions for this reaction have been published during the last decade [19-24].

\section{EXPERIMENTAL}

Melting points of the synthesized compounds were determined in open capillary tubes and were uncorrected. Reaction progress was observed by TLC plates, Bruker $400 \mathrm{MHz}$ instrument was used to record ${ }^{1} \mathrm{H}$ NMR and $100 \mathrm{MHz}$ for ${ }^{13} \mathrm{C}$ NMR spectra in DMSO using TMS as internal standard. Chemical shifts $(\delta)$ are expressed in ppm. The mass spectra were measured on a GC/MS-QP1000EX (EI, $70 \mathrm{eV}$ ) mass spectrometer. Elemental analyses were performed on a PerkinElmer $240 \mathrm{CHN}$ analyser.

*Corresponding author. E-mail: kumargullapelli001@gmail.com

This work is licensed under the Creative Commons Attribution 4.0 International License 
General procedure for the synthesis of 1-substituted aryl-pyrroles (3a-h)

Oxone $(0.09 \mathrm{~g}, 0.30 \mathrm{mmol})$ was added to a solution of the aromatic primary amines $(2.5 \mathrm{mmol})$ and 2,5-dimethoxytetrahydrofuron $(3.0 \mathrm{mmol})$ in a solvent $(5 \mathrm{~mL})$ was further added (Scheme 1). The reaction mixture was heated under microwave irradiation for $10 \mathrm{~min}$ at $110 \pm 10{ }^{\circ} \mathrm{C}$. The reaction mixture was irradiated until total consumption of the amine was verified by TLC. Water was added and the products were extracted with EtOAc $(3 \times 20 \mathrm{~mL})$. The organic phase was dried over anhydrous $\mathrm{MgSO}_{4}$ and the solvent was removed under reduced pressure. The product was purified on a silica gel column chromatography eluted with mixture of ethyl acetate/hexane (1:4) to afford the product.

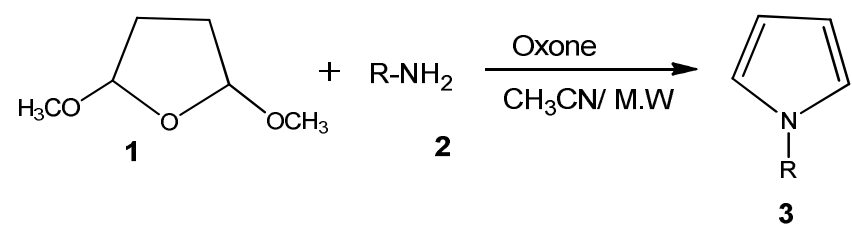

Scheme 1

Characteristic data of synthesised compounds

1-Phenyl-1H-pyrrole (3a). M.P. 58-60 ${ }^{\circ} \mathrm{C} ;{ }^{1} \mathrm{H}$ NMR (DMSO- $\mathrm{d}_{6}, 400 \mathrm{MHz}, \delta$ in ppm): 7.38-7.35 $(\mathrm{m}, 4 \mathrm{H}), 7.24-7.17(\mathrm{~m}, 1 \mathrm{H}), 7.08(\mathrm{~m}, 2 \mathrm{H}), 6.35-6.33(\mathrm{~m}, 2 \mathrm{H}) .{ }^{13} \mathrm{C}$ NMR (DMSO-d $6,100 \mathrm{MHz}$, $\delta$ in ppm): $140.7,129.5,125.5,120.4,119.2,110.3$. MS, $m / z(\%), 143\left(\mathrm{M}^{+}\right)$. Anal. calcd. for $\mathrm{C}_{10} \mathrm{H}_{9} \mathrm{~N} ; \mathrm{C}, 83.88 ; \mathrm{H}, 6.34 ; \mathrm{N}, 9.78$. Found: $\mathrm{C}, 82.50 ; \mathrm{H}, 6.30 ; \mathrm{N}, 9.52$.

1-p-Tolyl-1H-pyrrole (3b). M.P. 80-82 ${ }^{\circ} \mathrm{C} ;{ }^{1} \mathrm{H}$ NMR (DMSO- $\mathrm{d}_{6}, 400 \mathrm{MHz}, \delta$ in ppm): 7.27 (d, $J$ $=8.3 \mathrm{~Hz}, 2 \mathrm{H}), 7.19(\mathrm{~d}, J=8.3 \mathrm{~Hz}, 2 \mathrm{H}), 7.06-7.04(\mathrm{~m}, 2 \mathrm{H}), 6.34-6.32(\mathrm{~m}, 2 \mathrm{H}), 2.36(\mathrm{~s}, 3 \mathrm{H}) .{ }^{13} \mathrm{C}$ NMR (DMSO-d $\mathrm{d}_{6}, 100 \mathrm{MHz}, \delta$ in ppm): 138.4, 135.2, 130.0, 120.4, 119.2, 110.0, 20.8. MS, $\mathrm{m} / \mathrm{z}$ $(\%), 158\left(\mathrm{M}^{+}\right)$. Anal. calcd. for $\mathrm{C}_{11} \mathrm{H}_{11} \mathrm{~N} ; \mathrm{C}, 84.04 ; \mathrm{H}, 7.05 ; \mathrm{N}, 8.91$. Found: $\mathrm{C}, 83.50 ; \mathrm{H}, 6.85$; $\mathrm{N}, 8.25$.

1-(4-Methoxy phenyl)-1H-pyrrole (3c). M.P. $108-110{ }^{\circ} \mathrm{C} ;{ }^{1} \mathrm{H}$ NMR (DMSO- $\mathrm{d}_{6}, 400 \mathrm{MHz}, \delta$ in ppm): 7.30 (d, $J=8.6 \mathrm{~Hz}, 2 \mathrm{H}), 6.94(\mathrm{~d}, J=8.6 \mathrm{~Hz}, 2 \mathrm{H}), 7.10-6.99(\mathrm{~m}, 2 \mathrm{H}), 6.33-6.31(\mathrm{~m}, 2 \mathrm{H})$, $3.82(\mathrm{~s}, 3 \mathrm{H}) .{ }^{13} \mathrm{C}$ NMR (DMSO-d ${ }_{6}, 100 \mathrm{MHz}, \delta$ in ppm): 157.5, 134.4, 122.1, 119.6, 114.6, 109.8, 55.4. MS, $m / z(\%), 173\left(\mathrm{M}^{+}\right)$. Anal. calcd. for $\mathrm{C}_{11} \mathrm{H}_{11} \mathrm{NO} ; \mathrm{C}, 76.28 ; \mathrm{H}, 6.40 ; \mathrm{N}, 8.08$. Found: C, 75.85; H, 6.05; N, 7.95.

(4-Nitrophenyl)-1H-pyrrole (3d). M.P. $182-183{ }^{\circ} \mathrm{C} ;{ }^{1} \mathrm{H}$ NMR (DMSO- $\mathrm{d}_{6}, 400 \mathrm{MHz}, \delta$ in ppm): $8.31(\mathrm{~d}, J=8.9 \mathrm{~Hz}, 2 \mathrm{H}), 7.51(\mathrm{~d}, J=8.9 \mathrm{~Hz}, 2 \mathrm{H}), 7.18-7.17(\mathrm{~m}, 2 \mathrm{H}), 6.43-6.42(\mathrm{~m}, 2 \mathrm{H}) .{ }^{13} \mathrm{C}$ NMR (DMSO-d ${ }_{6}, 100 \mathrm{MHz}, \delta$ in ppm): 144.5, 143.8, 125.4, 119.3, 118.8, 112.2. MS, $\mathrm{m} / z(\%)$, $188\left(\mathrm{M}^{+}\right)$. Anal. calcd. for $\mathrm{C}_{10} \mathrm{H}_{8} \mathrm{~N}_{2} \mathrm{O}_{2} ; \mathrm{C}, 63.82 ; \mathrm{H}, 4.28 ; \mathrm{N}, 14.89$. Found: $\mathrm{C}, 63.25 ; \mathrm{H}, 4.20 ; \mathrm{N}$, 14.35.

(4-Chlorophenyl)-1H-pyrrole (3e). M.P. 86-88 ${ }^{\circ} \mathrm{C} ;{ }^{1} \mathrm{H}$ NMR (DMSO-d $\mathrm{d}_{6}, 400 \mathrm{MHz}, \delta$ in ppm): $7.39(\mathrm{~d}, J=9.2 \mathrm{~Hz}, 2 \mathrm{H}), 7.31(\mathrm{~d}, J=9.2 \mathrm{~Hz} 2 \mathrm{H}), 7.04(\mathrm{~m}, 2 \mathrm{H}), 6.35(\mathrm{~m}, 2 \mathrm{H}) .{ }^{13} \mathrm{C} \mathrm{NMR}$ $\left(\mathrm{DMSO}_{6}, 100 \mathrm{MHz}, \delta\right.$ in ppm): $139.2,130.9,129.5,121.5,119.2,110.8$. MS, $\mathrm{m} / z(\%), 179$ $\left(\mathrm{M}^{+}\right)$. Anal. calcd. for $\mathrm{C}_{10} \mathrm{H}_{8} \mathrm{~N}_{2} \mathrm{O}_{2} ; \mathrm{C}, 67.62 ; \mathrm{H}, 4.54 ; \mathrm{N}, 7.89$; Found: $\mathrm{C}, 61.25 ; \mathrm{H}, 4.30 ; \mathrm{N}, 7.49$.

4-((1H-pyrrol-1-yl) sulfonyl) aniline (3g). M.P. $247-250{ }^{\circ} \mathrm{C} ;{ }^{1} \mathrm{H}$ NMR (DMSO- $\mathrm{d}_{6}, 400 \mathrm{MHz}, \delta$ in ppm): 7.98 (d, $J=8.9 \mathrm{~Hz}, 2 \mathrm{H}), 7.74(\mathrm{~d}, J=8.9 \mathrm{~Hz}, 2 \mathrm{H}), 7.39(2 \mathrm{H}), 6.61(\mathrm{~s}, 2 \mathrm{H}), 6.35$ (t, $J=$ 
A facile synthesis of 1-aryl pyrroles by Clauson-Kaas reaction using Oxone as a catalyst 145

$2.4 \mathrm{~Hz}, 2 \mathrm{H}) ;{ }^{13} \mathrm{C}$ NMR (DMSO-d $6,100 \mathrm{MHz}, \delta$ in ppm): 143.9, 141.6, 128.8, 120.2, 119.9, 112.3. MS, $m / z(\%), 222\left(\mathrm{M}^{+}\right)$. Anal. calcd. for $\mathrm{C}_{10} \mathrm{H}_{10} \mathrm{~N}_{2} \mathrm{O}_{2} \mathrm{~S} ; \mathrm{C}, 54.04 ; \mathrm{H}, 4.54 ; \mathrm{N}, 12.60$; Found: C, 53.95; H, 4.30; N, 12.19 .

1-(4-Nitrophenyl sulfonyl)-1H-pyrrole (3h). M.P. 137-139 ${ }^{\circ} \mathrm{C} ;{ }^{1} \mathrm{H}$ NMR (DMSO- $\mathrm{d}_{6}, 400 \mathrm{MHz}, \delta$ in ppm): $8.34(\mathrm{~d}, J=8.7 \mathrm{~Hz}, 2 \mathrm{H}), 8.02(\mathrm{~d}, J=8.7 \mathrm{~Hz}, 2 \mathrm{H}), 7.16(\mathrm{t}, J=2.3 \mathrm{~Hz}, 2 \mathrm{H}), 6.35(\mathrm{t}, J=$ $2.3 \mathrm{~Hz}, 2 \mathrm{H}$ ); ${ }^{13} \mathrm{C}$ NMR (DMSO-d ${ }_{6}, 100 \mathrm{MHz}, \delta$ in ppm): 150.6, 144.4, 128.1, 124.6, 121.0, 114.8. MS m/z (\%), $252\left(\mathrm{M}^{+}\right)$. Anal. calcd. for $\mathrm{C}_{10} \mathrm{H}_{8} \mathrm{~N}_{2} \mathrm{O}_{4} \mathrm{~S} ; \mathrm{C}, 47.61 ; \mathrm{H}, 3.20 ; \mathrm{N}, 11.11$; Found: C, 47.05; H, 3.02; N, 10.89 .

Table 1. Compounds and yields.

\begin{tabular}{|c|c|c|c|}
\hline Entry & Compound & Time (min) & Yield (\%) \\
\hline $3 \mathbf{a}$ & & 10 & 80 \\
\hline $3 b$ & & 16 & 78 \\
\hline $3 c$ & & 18 & 76 \\
\hline 3d & & 15 & 75 \\
\hline $3 e$ & & 16 & 72 \\
\hline $3 f$ & & 19 & 70 \\
\hline $3 g$ & & 22 & 68 \\
\hline $3 \mathrm{~h}$ & & 20 & 65 \\
\hline $3 \mathbf{i}$ & & 18 & 70 \\
\hline $3 \mathbf{j}$ & & 14 & 65 \\
\hline
\end{tabular}

Bull. Chem. Soc. Ethiop. 2019, 33(1) 


\section{RESULTS AND DISCUSSION}

In the present work, a new methodology for the synthesis of 1-aryl pyrroles 3 has been described by a Clauson-Kaas reaction employing three-component synthesis of pyrrole derivatives by using catalytic amount of Oxone. The catalyst Oxone $\left(2 \mathrm{KHSO}_{5} \cdot \mathrm{KHSO}_{4} \cdot \mathrm{K}_{2} \mathrm{SO}_{4}\right)$ is a transition-metal-free, mild and easy to handle, not toxic, cheap and stable commercial product and used various organic transformations [25-28]. In the present study, the catalyst Oxone involving in the efficient synthesis of aryl pyrroles is shown by mechanism in Figure 1. The reaction was performed in acetonitrile at $110{ }^{\circ} \mathrm{C}$ under microwave irradiation.

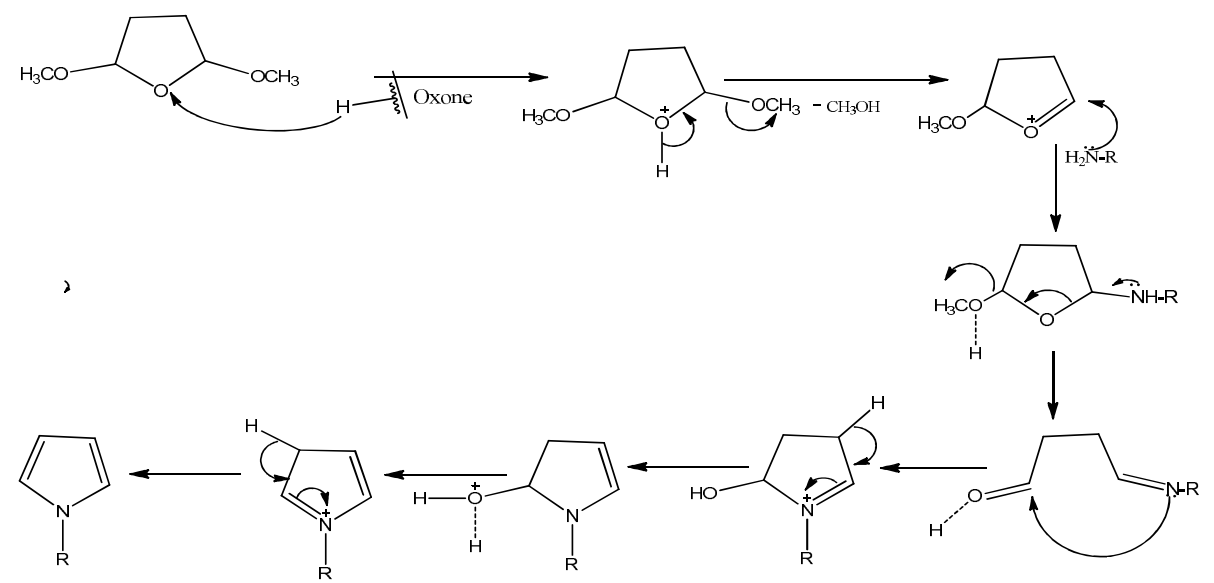

Figure 1. Possible mechanism for Oxone supported synthesis of 1-substituted aryl-pyrroles.

In order to establish the best conditions, the investigation started with the reaction of primary amines $(2.5 \mathrm{mmol})$ and 2,5-dimethoxytetrahydrofuran $(3.0 \mathrm{mmol})$. The influence of various solvents and amount of catalyst were verified. Running the reaction with $0.30 \mathrm{mmol}$ of Oxone in the solvent free conditions gave $60 \%$ yield of $\mathbf{3 a}$ after 20 min (Table 1, entry 5). Use of ethanol as solvent improved the yields to $75 \%$ (Table 2, entry 1), employing water afforded $55 \%$ of $3 \mathbf{a}$ (Table 2 , entry 6 ). Better yields were observed in acetonitrile $(80 \%)$ which also shortened the reaction time to $10 \mathrm{~min}$ (Table 2, entry 2). Therefore, the latter was selected as the solvent of choice. Next, effect of the nature and quantity of catalyst added on the reaction performance were evaluated. The reaction was performed under microwave irradiation, which furnished comparable yields in shorter times (Table 1, entries 3a-j). These results suggested that the best condition required is use of $0.30 \mathrm{mmol}$ of Oxone in refluxing acetonitrile. In order to find out the scope and limitations of the method, the reaction was extended to other amines employing the optimized conditions (Table 2). The aromatic amines furnished the products in good to excellent yields after 10-22 min of reaction under microwave irradiation.

Table 2. Optimization of reaction conditions.

\begin{tabular}{|c|c|c|c|c|}
\hline Entry & Solvent & Oxone ${ }^{\circledR}$ & Time (min) & Yield (\%) \\
\hline 1 & Ethanol & $0.09 \mathrm{~g}$ & 12 & 75 \\
\hline 2 & Acetonitrile & $0.09 \mathrm{~g}$ & 10 & 80 \\
\hline 3 & DMF & $0.09 \mathrm{~g}$ & 13 & 70 \\
\hline 4 & THF & $0.09 \mathrm{~g}$ & 16 & 72 \\
\hline 5 & Solvent free & $0.09 \mathrm{~g}$ & 20 & 60 \\
\hline 6 & $\mathrm{H}_{2} \mathrm{O}$ & $0.09 \mathrm{~g}$ & 22 & 55 \\
\hline
\end{tabular}

Bull. Chem. Soc. Ethiop. 2019, 33(1) 


\section{CONCLUSION}

It has been shown that Oxone is a highly convenient catalyst for the Clauson-Kaas reaction of 2,5-dimethoxytetrahydrofuran with aryl amines, cleanly furnishing excellent yields of $\mathrm{N}$-aryl pyrroles, under microwave irradiation in short reaction times. In conclusion, a new protocol has been developed for the synthesis of pyrroles using microwave irradiation and Oxone as catalyst. The products were obtained in high yields and with shorter reaction times.

\section{ACKNOWLEDGEMENTS}

The authors gratefully acknowledge the Department of Chemistry, Kakatiya University, Warangal and Management, Principal of Mahatma Gandhi Institute of Technology-Hyderabad, for their constant support during this research work.

\section{REFERENCES}

1. Ciufolini, M.A. Synthetic studies on heterocyclic natural products. Il Farmaco. 2005, 60, 627-641.

2. Jingpei, H.; Huawen, H.; Min, Z.; Xiaohong, H.; Min, C.; Dongchu, C.; Jinwen, L.; Guifeng, X.; Yang, W.; Zhongliu, W. A mini review of the synthesis of poly-1,2,3-triazole-based functional materials. RSC Adv. 2017, 7, 2281-2287.

3. Arjmand, F.; Mohani, B.; Ahmad, S.; Synthesis, antibacterial, antifungal activity and interaction of CT-DNA with a new benzimidazole derived $\mathrm{Cu}(\mathrm{II})$ complex. Eur. J. Med. Chem. 2005, 4, 1103-1110.

4. Galal, S.A.; Abdelsamie, A.S.; Rodriguez, M.L.; Kerwin, S.M.; El Diwani, H.I. Synthesis and studying the antitumor activity of novel 5-(2-methylbenzimidazol-5-yl)-1,3,4oxadiazole-2(3H)-thiones. Eur. J. Chem. 2010, 1, 67-72.

5. Wardakhan, W.W.; Samir, E.M.; El-Arab, E.E. Synthesis and cytotoxicity of novel thiophene, pyran and pyridine derivatives. Bull. Chem. Soc. Ethiop. 2018, 32, 259-270.

6. Gulapelli, K.; Brahmeshwari, G.; Ravichander, M.; Uma, K. Synthesis, antibacterial and molecular docking studies of new benzimidazole derivatives. Egyptian J. Basic Appl. Sci. 2017, 4, 303-309.

7. Mohammed Hussain, A.; Sheik Mansoor, S.; Aswin, K.; Logaiya, K.; Sudhan, S.P.N.; Synthesis and in vitro antimicrobial evaluation of 5-amino-7-aryl-6-cyano- $4 H$ pyrano[3,2,b] pyrrole derivatives catalyzed by reusable $\mathrm{ZrOCl}_{2} \cdot 8 \mathrm{H}_{2} \mathrm{O}$. Bull. Chem. Soc. Ethiop. 2014, 28, 91-100.

8. Akbar, I.; Radhakrishnan, S.K.; Abdul Jamal, A.N. Synthesis, characterization and antimicrobial activity of new pyrrole derivatives. J. Mexican Chem. Soc. 2011, 55, 218-223.

9. Pegklidou, K.; Papastavrou, N.; Gkizis, P.; Komiotis, D.; Balzarini, J.; Nicolaou, I.; Nsubstituted pyrrole-based scaffolds as potential anticancer and antiviral lead structures. Med. Chem. 2015, 11, 602-608.

10. Toshikazu, B.; Hirokazu, I.; Zhi-Fu, T.; Akihiko, N.; Noboru, F.; Takao, Y.; Hiroshi, S. Sequence specificity, reactivity, and antitumor activity of DNA-alkylating pyrrole-imidazole diamides. Chem. Biol. 2003, 10, 751-758.

11. Mohamed, M.S.; Kamel, R.; Fathallah, S.S. Synthesis of new pyrroles of potential antiinflammatory activity. Arch. Pharm. Chem. Life Sci. 2011, 344, 830-839.

12. MacLean, P.D.; Chapman, E.E.; Dobrowolski, S.L.; Thompson, A.; Barclay, L.R.C. Pyrroles as antioxidants: Solvent effects and the nature of the attacking radical on antioxidant activities and mechanisms of pyrroles, dipyrrinones, and bile pigments. J. Org. Chem. 2008, 73, 6623-6635.

Bull. Chem. Soc. Ethiop. 2019, 33(1) 
13. Katsoulidis, A.P.; $\quad$ Dyar, S.M.; $\quad$ Carmieli, R.; $\quad$ Malliakas, C.D.; Wasielewski, M.R.; Kanatzidis, M.G. Copolymerization of terephthalaldehyde with pyrrole, indole and carbazole gives microporous POFs functionalized with unpaired electrons. J. Mater. Chem. 2013, 1, 10465-10473.

14. Antonio, F.; Alessandro, A.; Luca, B.; Milko, E.; Vander, B.; Pulak, D.; Guennadi, E.; Giorgo, A.P.; Tobin J.M. Layer-by-layer self-assembled pyrrole-based donor-acceptor chromospheres as electro-optic materials. Chem. Mater. 2003, 15, 1064-1072.

15. Gourlay, B.S.; Molesworth, P.P.; Ryan, J.H.; Smith, J.A. A new and high yielding synthesis of unstable pyrroles via a modified Clauson-Kaas reaction. Tetrahedron Lett. 2006, 47, 799801.

16. Zhang, X.; Shi, J. Unique chemo selective Clauson-Kaas reaction of substituted aniline catalyzed by $\mathrm{MgI}_{2}$ etherate. Tetrahedron 2011, 67, 898-903.

17. Rivera, S.; Bandyopadhyay, D.; Banik, B.K. Facile synthesis of N-substituted pyrroles via microwave-induced bismuth nitrate-catalyzed reaction. Tetrahedron Lett. 2009, 50, 54455448.

18. Clauson-Kaas, N.; Tyle, Z. Preparationofcis-andtrans-2,5-dimethoxy-2-(acetamidomethyl)2,5-dihydrofuran, of cis- and trans-2,5-dimethoxy-2-(acetamidomethyl)-tetrahydrofuran, and of 1-phenyl-2(acetamidomethyl)pyrrole. Acta Chem. Scand. 1952, 6, 667-670.

19. Omid, M.; Hossein, T.N. Grinding solvent-free Paal-Knorr pyrrole synthesis on smectites as recyclable and green catalysts. Bull. Chem. Soc. Ethiop. 2018, 32, 139-147.

20. Brendon, S.G.; Peter, P.M.; John, H.R.; Jason, A.S. A new and high yielding synthesis of unstable pyrroles via a modified Clauson-Kaas reaction. Tetrahedron Lett. 2006, 47, 799801.

21. Wilson, M.; Filzen, G.; Welkmaker, G.S. A microwave-assisted, green procedure for the synthesis of N-aryl sulfonyl and N-aryl pyrroles. Tetrahedron Lett. 2009, 50, 4807-4809.

22. Joseph, P.Y.K.; Sukumaran, M.; Peter, Y.Z.; Steven, F.; Gerald, M.R. Baeyer-Villiger rearrangement of a substituted pyrrole by Oxone. Tetrahedron Lett. 2014, 55, 3111-3113.

23. Zuo, B.; Chen, J.; Liu, M.; Ding, J.; Wu, H.; Su, W. Scandium triflate catalyzed synthesis of $\mathrm{N}$-substituted pyrroles from amine and 2,5-dimethoxytetrahydrofuran. J. Chem. Res. 2009, 1, 14-16.

24. Bandyopadhyay, D.; Sanghamitra, M.; Banik, B.K. An expeditious synthesis of Nsubstituted pyrroles via microwave-induced iodine-catalyzed reactions under solventless conditions. Molecules 2010, 15, 2520-2525.

25. Rivera, S.; Bandyopadhyay, D.; Banik, B.K. Facile synthesis of N-Substituted pyrroles via microwave-induced bismuth nitrate-catalyzed reaction. Tetrahedron Lett. 2009, 50, 54455448 .

26. Gullapelli, K.; Brahmeshwari, G.; Ravichander, M.; Jagadeesh Babu, K.; Srinivas, B. A simple and efficient, silica supported Oxone catalyzed one-pot synthesis of 2-arylbenzimidazoles. Der Pharma Chemica 2018, 10, 50-52.

27. Travis, B.R.; Sivakumar,M.; Hollist, G.O.; Borhan, B. Facile oxidation of aldehydes to acids and esters with Oxone. Org. Lett. 2003, 5, 1031-1034.

28. Joseph, P.Y.K.; Sukumaran, M.; Peter, Y.Z.; Steven, F.; Gerald, M.R. Baeyer-Villiger rearrangement of a substituted pyrrole by Oxone. Tetrahedron Lett. 2014, 55, 3111-3113. 